\title{
Degradation Study of Biodegradable Plastic Using Nata De Coco as A Filler
}

\author{
Tiara Nur Elfiana ${ }^{1}$, Anisa Nur Izza Fitria ${ }^{2}{ }^{2}$, Endaruji Sedyadi ${ }^{1}$, Susy Yunita Prabawati ${ }^{1}$, Irwan $_{\text {Nugraha }}{ }^{1}$ \\ ${ }^{1}$ Chemistry Department, ${ }^{2}$ Chemistry Education Department, Faculty of Science and Technology, UIN Sunan Kalijaga \\ Jl. Marsda Adisucipto, No. 1 Yogyakarta 55281, Tel. +62-274-540971, Fax. +62-274-519739, Indonesia.
}

Author correspondency*:

anisanurizza17@yahoo.com

\begin{abstract}
Starch is known as a biodegradable raw material that can be degraded by bacteria and microorganisms in the soil. Starch has cellulose which is kind of plant cellulose. This study shows the biodegradation rates of plastic made from Ganyong Canna (Canna edulis Kerr) as a cellulose source which is added with nata de coco as a filler. The biodegradable plastic functional group was confirmed by using FITR The results show that the O-H group of Ganyong Canna (Canna edulis Kerr) biodegradable plastic is located at wave number $3298.03 \mathrm{~cm}$ ${ }^{1}$ and shifted to $3290.32 \mathrm{~cm}^{-1}$ after addition of nata de coco. The C-H bonds functional groups in Canna biodegradable plastics and nata de coco plastics are at wave numbers $2920.01 \mathrm{~cm}^{-1}$ and $2916.16 \mathrm{~cm}^{-1}$. While the $\mathrm{C}-\mathrm{O}$ bonds functional groups in biodegradable starch plastics and nata de coco is shown at wave numbers $995.05 \mathrm{~cm}^{-1}$. The mechanical properties of biodegradable plastics testing are thickness, tensile strength, and elongation based on the ASTM method. The thickness is about $0.1005 \mathrm{~mm}$, the tensile strength of biodegradable plastic is 4,3244 $\mathrm{MPa}$ and the elongation value range about $13.9639 \%$ while the WVTR range about $14.20 \mathrm{~g} / \mathrm{m}^{2}$ hours. The results show that the increase of the plastic degradation made from nata de coco occurs between $5 \%$ - 38\% per days. It is faster than the plastic made from pure Ganyong Canna (Canna edulis Kerr) starch. These results indicate that nata de coco could be added in biodegradable plastic on packaging materials for better degradation.
\end{abstract}

Keywords: Biodegradable; Cellulose; Ganyong canna; Nata de coco

\section{INTRODUCTION}

Biodegradable plastic has been predicted being an alternative for environmental problem in the last few decades. Biodegradable plastics have the ability to degrade faster than synthetic plastic which is approximately degraded in 50 years for a foam plastic cup (Roohi, 2017). The polymer in plastics changes into $\mathrm{CO}_{2}$ and $\mathrm{H}_{2} \mathrm{O}$ in combination of microorganism in the soil (Kumar Satish and Thakur, 2017). The $\mathrm{CO}_{2}$ would be used by plants in photosynthesis while the water would dissolve in the soil pores so that biodegradable material would not be harmful in environment.

The main constituents of biodegradable plastic are cellulose. The cellulose sources are mostly from plants, such as wood and agricultural waste (Mostafa et al., 2018). However, plant cellulose has other components such as lignin, so it needs separation process to get pure cellulose. The purifications has been carried out by $\mathrm{Vu}$ Ngo Dinh et al. (2017) using an Ultrasound-Assisted Alkaline methods which required high technology and costs.

Biodegradable is known as rigid therefore plasticizers are needed to produce the plastic which is more elastic, flexible and resistant to water. One plasticizer that is widely used in manufacture of biodegradable plastics is glycerol. Biodegradable plastic from hydrocolloids such as nata de coco and Ganyong canna (Canna edulis Kerr) has a high polarity and it is hydrophilic which produces high water vapor permeability and low oxygen permeability. This is due to the presence of hydrogen bonds in the molecular structure. Therefore, it is necessary to add lipids such fatty acids that have low polarity in order to reduce water vapor permeability.

Saturated fatty acids have hydroxyl groups that are hydrophobic so they can reduce hydrophilic properties. One type of saturated fatty acid that can be used is palmitic acid (Krocta, 1994). According to Lay and Huey (1997), the addition of palmitic acid into the film aims to protect the product against evaporation of moisture. This is related to the ability of palmitic acid to improve the hydrophobic nature of a solution.

Nata de coco is a food product with high cellulose in the coconut water with excellent minerals such as $\mathrm{K}, \mathrm{Cl}$, $\mathrm{S}, \mathrm{Ca}, \mathrm{Na}, \mathrm{Mg}$, etc. The sugars content, sucrose, sorbitol, glucose and fructose, are the needs of Acetobacter axylum in fermentation process (Alexia, 2012). These bacteria produced a million of biomass grown by appearing solid white to transparent in the number of mass about $250 \mathrm{~g} / \mathrm{L}$ wet weight of cellulose (Gayathri, 2015). Nowadays, nata de coco is just served as a food desert without any utilizing improvement even thought it has a high tensile strength and biodegradable properties. 
In order to meet the need of biodegradable plastic, this paper shows the study of nata de coco as a filler in combination with Ganyong canna (Canna edulis Kerr) as a starch sources including an analyzing of the physical and mechanical properties, thickness, tensile strength, elongation, water vapor permeability and molecular interactions between nata de coco and starch using FT-IR instrument.

\section{MATERIALS AND METHODS}

The materials used in this study was Ganyong Canna (Canna edulis Kerr) which were the basic ingredients for biodegradable plastics. This canna obtained from Regedeg Village, Gunung Kidul Regency. Other ingredients used was nata de coco, aquades, a soil for degradation media, sodium hydroxide, glycerol, acetic acid.

\section{Preparations of Nata de coco Pulp}

Nata de coco was heated with $1 \% \mathrm{NaOH}$ for 60 minutes. This suspension then washed with water and followed by boiling for the second time in water. The nata de coco soaked in water for one night. Pulping was done by smoothing nata de coco using a blender and used for the manufacture of biodegradable plastics. Afer that, the pulp dried using an oven at $60{ }^{\circ} \mathrm{C}$.

\section{Preparations of Ganyong Canna (Canna edulis Kerr) Starch}

Ganyong Canna starch was produced by adding water to dried Ganyong Canna (Canna edulis Kerr) and mashed into a pulp. The dregs and the starch were separated by filtering with a filter cloth. The filtration results were left for one night until the starch settles. Then the resulting precipitate was dried using an oven at $60{ }^{\circ} \mathrm{C}$.

\section{Preparations of Biodegradable Plastics}

First of all, 1.5 gram Ganyong canna starch was dissolved with distilled water. The solution was added with $0.75 \mathrm{ml}$ of glycerol and $1.5 \mathrm{~mL}$ of acetic acid. Then, the solution was added to a volume of $100 \mathrm{ml}$ of distilled water and followed by heating at a temperature of $80-90{ }^{\circ} \mathrm{C}$ until homogeneous for 25 minutes. The mixtures were cooled. The air bubbles and impurities were removed. The mixtures were added to nata de coco pulp in $0.5 ; 1.0 ; 1.5$; and 3.0 grams and poured into a solution casting size of $30 \times 20 \mathrm{~cm}^{2}$ and dried in an oven at $60{ }^{\circ} \mathrm{C}$ for 2 hours. The mold was removed and left at room temperature for 24 hours.

\section{Data Analysis}

Biodegradable plastic was analyzed its functional group using FTIR. Samples in the form of plastic were placed into a set holder, then the plastic was scanned at a wavelength of $4000-400 \mathrm{~cm}^{-1}$.
The mechanical properties of biodegradable plastics were tested including thickness, tensile strength, and elongation based on the ASTM method. D. 882-02. Thickness was measured using a micrometer (accuracy of $0.001 \mathrm{~mm}$ ) by placing a sample between the micrometer jaw. For each plastic sample to be tested, measurements were made at 3 different points, then the mean value was calculated.

The tensile strength and elongation of biodegradable plastic samples were tested using Universal Testing Machine (UTM). The plastic was placed at room temperature $\left(30{ }^{\circ} \mathrm{C}\right)$ for 24 hours before measuring. Biodegradable plastic samples was placed at the second end of the clamp. The measurement area was set with the appropriate load and set to zero. The drive button and clamp was turned on and the sample test was observed until it broke. Tensile strength was determined based on maximum load, while elongation was determined when biodegradable plastic broke.

The water vapor transmission rate test was carried out using the gravimetric method (ASTM 1983). The biodegradable plastic that would be tested was placed in the mouth of a cup with a diameter of $8 \mathrm{~cm}$ which contained silica gel $10 \mathrm{~g}$. The edges of the cup and plastic were covered with rubber. The cup was put into a jar containing $\mathrm{NaCl}$ solution.

The water vapor diffused through biodegradable plastic would be absorbed by silica gel and would increase the mass of the silica gel. Then It was weighed every 1 hour for 6 hours (starting from 0 to 6 hours). Changing in the weight rate indicated the speed of water vapor diffusion through the biodegradable plastic. The data obtained was made by linear regression equation and WVTR value could be determined by the equation:

$$
W V T R=\frac{\text { Cup increase slope }\left(\frac{\text { gram }}{\text { hour }}\right)}{\text { Plastic surface area }\left(m^{2}\right)}
$$

Biodegradation test was carried out to determine how long plastic can be broken down by microorganisms (bacteria and fungi). The method used was soil burial test, which was planting and burying samples in the soil for 12 days. The soil was placed in a jar with a diameter of $13 \mathrm{~cm}$ and a height of $17 \mathrm{~cm}$.

Plastic samples measuring $3 \times 3 \mathrm{~cm}^{2}$ from Ganyong Canna (Canna edulis Kerr) starch and variations of nata de coco plastic buried in the soil with a depth of $5 \mathrm{~cm}$. Before being buried, biodegradable plastic was left in the desiccator for 24 hours then weighed (W1). Every 2 days, plastic was taken, washed with alcohol, dried in an oven and weighed for the second time (W2). The step was repeated for 12 days and the degradation mass was determined. 


\section{RESULTS AND DISCUSSION}

Biodegradable plastic can be decomposed naturally by microorganism's activities in the soil to harmless compounds when discharged into the environment. In this research, biodegradable plastic is made from renewable sources, Ganyong Canna (Canna edulis Kerr) as a base material, glycerol as plasticizer, acetic acid as terminator in polymerization reaction, distilled water as a solvent and modified by nata de coco.
The film characteristic of nata de coco indicates that the nata main component is a cellulose polymer. It can be seen on the peak absorption of nata de coco cellulose which is shown the $\mathrm{O}-\mathrm{H}$ groups in wave numbers at $3344.32 \mathrm{~cm}^{-1}$ and the $\mathrm{C}-\mathrm{O}$ bonds uptake at around $1029.21 \mathrm{~cm}^{-1}$, the $\mathrm{C}-\mathrm{H}$ absorption is at $2896.87 \mathrm{~cm}^{-1}$ and the $\mathrm{C}-\mathrm{C}$ is around at $1643.23 \mathrm{~cm}^{-1}$.

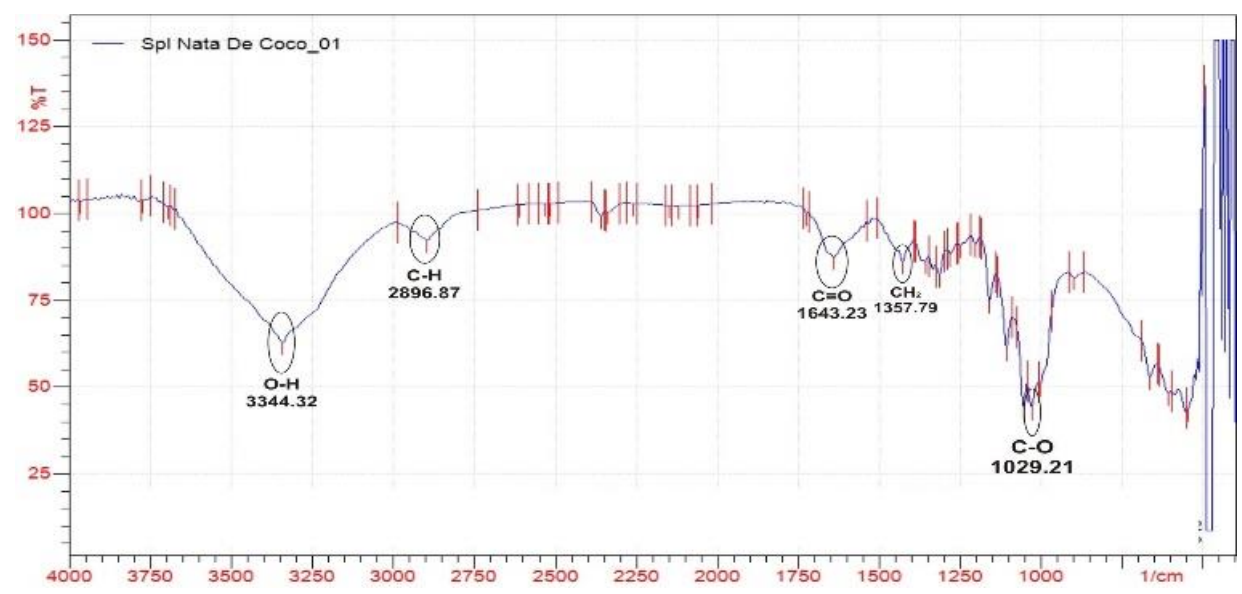

Figure 1. FTIR Spectrum of Ganyong Canna (Canna edulis Kerr).

The identification of functional groups is carried out at wave numbers $400-4000 \mathrm{~cm}-1$. The spectrum of Ganyong Canna (Canna edulis Kerr) starch shows a widened absorption at wavenumber $3355.89 \mathrm{~cm}-1$ which indicate the presence of $\mathrm{O}-\mathrm{H}$ stretching groups. The absorption of C-H is at wave number $2927.73 \mathrm{~cm}-1$. This is reinforced of the absorption band around 1357.79 $\mathrm{cm}-1$ which indicates the presence of $\mathrm{CH} 2$ groups. The other functional group is ether $(\mathrm{C}-\mathrm{O})$ which is shown at
$999.05 \mathrm{~cm}-1$. This result indicates that the functional groups are in accordance with the structure of the constituent components of starch, hydroxyl, methyl, and ether.

Analyzing FTIR to find out the functions in biodegradable plastic. In figure 2, biodegradable plastic spectra is seen the FTIR spectra of biodegradable plastics, Ganyong canna and nata de coco.

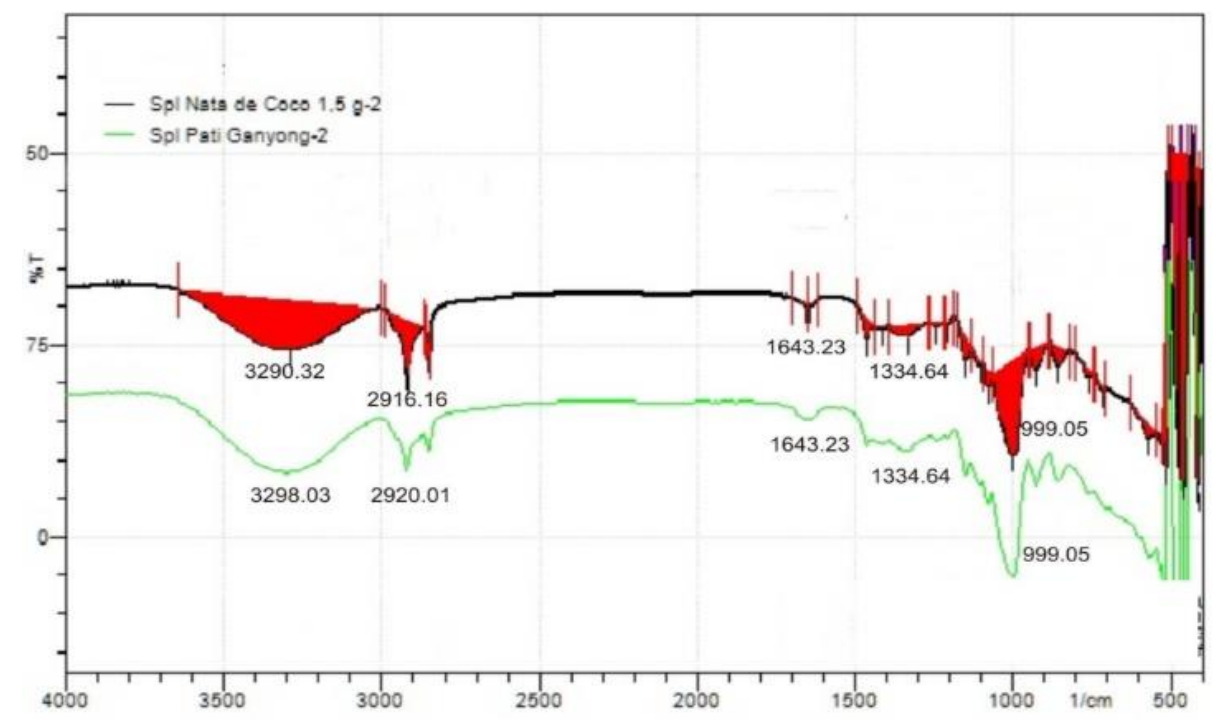

Figure 2. Spectra FTIR Biodegradable Plastic (a) Canna starch (b) Ganyong Starch-Nata de Coco $1.5 \mathrm{~g}$. 
It can be seen that the $\mathrm{OH}$ group is located at wave number 3298.03 and shifted to 3290 after the addition of nata de coco. The wave number of $\mathrm{C}-\mathrm{H}$ bond in Ganyong canna biodegradable plastic and nata de coco is shown at 2920, 01 and 2916.16. While the C-O bond in both components is found at wave number 995.05 (Sedyadi et al., 2016).

Starch-based biodegradable plastic is a type of condensation polymerization because it involves a hydroxyl group from one of the monosaccharides with hydroxyl groups from other monosaccharides through glycosidic. This biodegradable plastic has a rigid and easily broken nature because the hydrogen between polymers bonds are very strong, so it is necessary to add plasticizers (glycerol) to reduce hydrogen polymers to produce more elastic and flexible plastics (Wirawan et al., 2012). When glycerol was added some structural modifications occurred in the starch. The starch matrix became looser so the polymer chain moved more easily. It caused glycerol were being bridged between starch molecules by cross-linking between starch molecules with another molecules due to the interaction with the $\mathrm{OH}$ groups in the amylose and amylopectin structures (Kusnandar, 2010). The interaction between starch and glycerol could be seen in (figure 3).
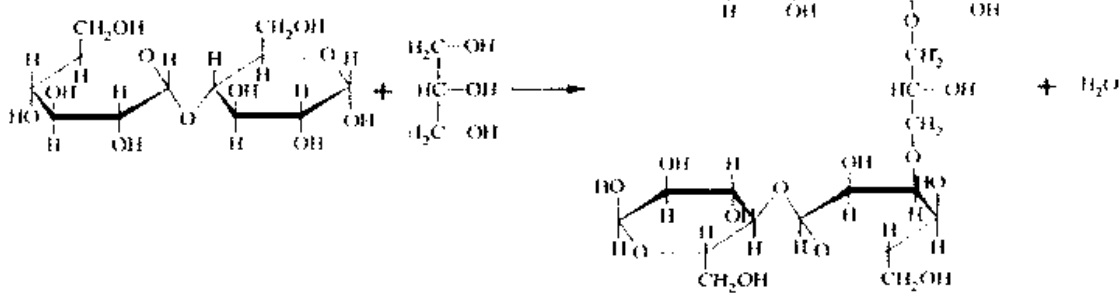

Figure 3. Strach and Glycerol reaction.

The plastic is used for packaging products mostly. Furthermore, In this application, the important thing is a thickness which is affected by the packaging of products. Thickness will affect gas permeability and other physical properties such as tensile strength and elongation (Sinaga et al., 2010). The thicker the plastic produced, the transmission of water vapor value was lower because the ability to hold water vapor would be greater.

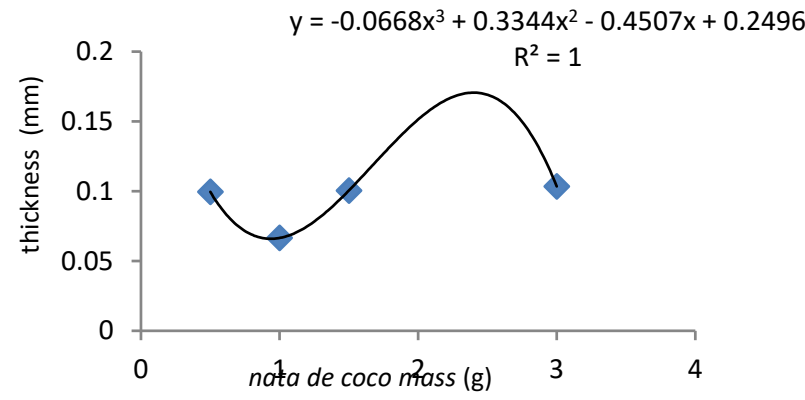

Figure 4. Thickness nata de coco plastic.

In Figure 4, the thickness shows the irregular value of nata de coco plastics. The plastic thickness on the 0.5 $\mathrm{g}$ and $1 \mathrm{~g}$ of nata de coco pulp decreases while the $1.5 \mathrm{~g}$ and $3 \mathrm{~g}$ of nata de coco pulp increase. These results caused the solution do not measure the same on printing process. The thicker the plastic produced, the lower the value of the transmission of water vapor because the greater the ability to hold water vapor. In this study, the thickness of biodegradable plastic is known from variations of nata de coco ranging from $0.0665 \mathrm{~mm}$ to $0.1035 \mathrm{~mm}$.

The measurement of plastic tensile strength is used to determine the amount of plastic receiving to achieve maximum pull (stretch) in each unit of plastic area. Testing of mechanical properties including tensile strength and elongation is very important to determine the strength in resisting the weight and elasticity of plastic.

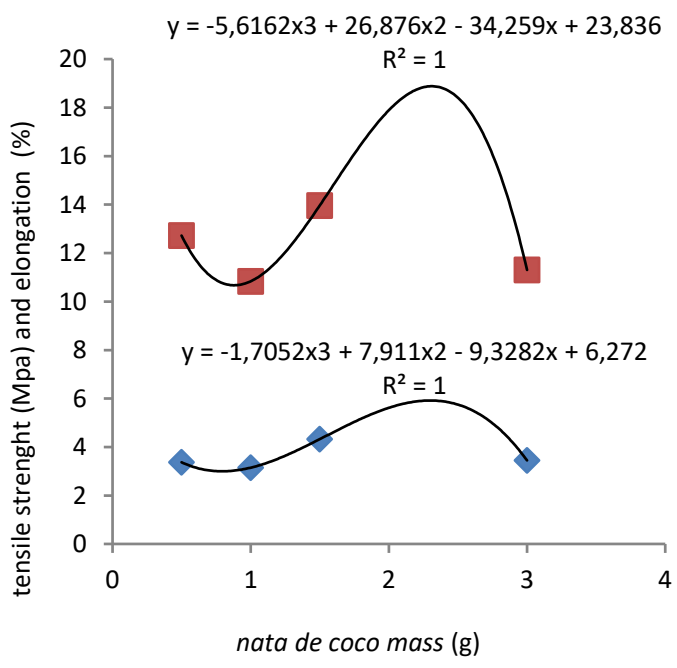

Figure 5. The tensile strength and elongation nata de coco plastic. 
Nata de coco which contained cellulose add tensile strength caused the bonding between hydroxyl $(\mathrm{O}-\mathrm{H})$ groups in starch with hydroxyl $(\mathrm{O}-\mathrm{H})$ and carboxyl $(\mathrm{COOH})$ groups in cellulose. In this study, the resulting tensile strength of biodegradable plastic is 4,3244 Mpa. The resulting value is higher than the research conducted by Mery Apriani (2014) which made biodegradable plastic using cassava starch which was given aloe vera with a tensile strength of $1.53 \mathrm{Mpa}$.

Measurement of tensile strength is also followed by measurement of elongation, namely the maximum changing in length before the plastic cut off. These properties is very important to indicate the ability of plastic to withstand a number of loads before the plastic is broken. Based on the results of the study shows that the elongation value ranged about $13.9639 \%$.

The tensile strength analysis has irregularities. This irregularity occurs because the solution is less homogeneous. There is inter-polysaccharide bonds broken up by glycerol occur unevenly in variations of nata de coco so that intermolecular interactions become reduced and affect the value of the tensile strength produced. This interaction occurs because glycerol inserts and removes the hydrogen bonds between polysaccharide molecules so the bonds between plastic molecules is weak (Bourtoom, 2008).

Other factors due to incomplete nata de coco mixing in plastic. The $0.5 \mathrm{~g}$ and $1.0 \mathrm{~g}$ of nata de coco mixing have low level of homogeneity so the increasing concentration of nata de coco does not produce strong increasing pull. The graph produced in addition to the mass of nata de coco is seen to be far away which proves that nata de coco in the solution does not give good homogeneity. While the addition of $1.5 \mathrm{~g}$ and $3.0 \mathrm{~g}$ of nata de coco has a graph that is mutually approaching which proves that the level of homogeneity in the mass of nata de coco is very good.

Nata de coco which contains cellulose will add tensile strength because cellulose is a reinforcing component in the composite material can increase its mechanical strength. The increase in tensile strength due to the addition of cellulose is caused by an increase in the interaction of the tensile forces between the molecules making up the thin layer. This condition is related to hydroxyl groups that form inter-intramolecular hydrogen bonds to form a thin layer consisting of fibers that are mutually reinforcing (Indriyati et al, 2006).

The rate of water vapor transmission is the amount of losing water vapor per unit time which divided by the area of plastic. Plastic that has the lowest wvtr value is probably good plastic.

Based on research shows that nata de coco plastic has high value of WVTR. Nata is a cellulose compound that is hydrophilic so the water is easily absorbed and migrated. The results show that the resulting WVTR value ranged from $14.20 \mathrm{~g} / \mathrm{m}^{2}$ hours. This wvtr value is better than one Italian company which produced biodegradable plastics named Bi Mater. It made from starch polymer with WVTR values of $250-1000 \mathrm{~g} / \mathrm{m}^{2}$ hours.

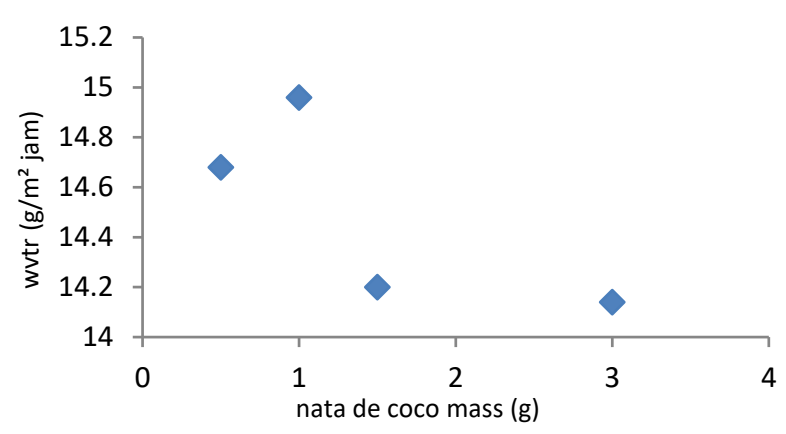

Figure 6. Water vapor transmission nata de coco plastic.

Biodegradation test was conducted to find out how fast biodegradable plastic could be degraded by microorganisms when discharged into the environment. In this study, biodegradation test was carried out using soil media because many microorganisms in the soil which could support the plastic degradation process. According to Sari (2007), soil moisture is very influential on the degradation process because it will facilitate microbes in consuming plastic as a food source. Another factor are $\mathrm{pH}$, temperature, carbon/ nitrogen sources, presence of contaminants, presence availability of nutrients (Roohi, 2017).

The biodegradation process was carried out by observing the plastics. Observations was done by looking at the changing of plastic visually and by weighing the decrease in plastic mass. Observations were made for 12 days, where every 2 days the plastic was taken from the soil and then washed and weighed. The results of the degradation of biodegradable plastic mass could be seen in (figure 7).

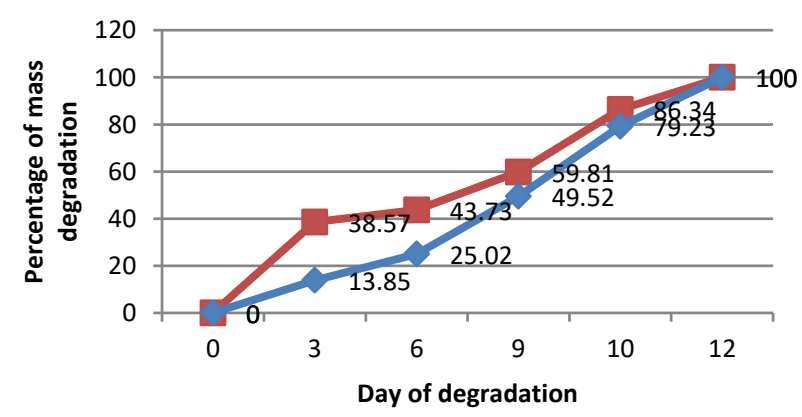

Figure 7. Biodegradable plastic mass degradation.

Based on the data, the plastic which was contained nata de coco as filler has more mass degradation than plastic in pure Ganyong canna. The percentage mass degradation was between 5\%-38\% depending on how long the plastic in the soil. In the early days, degradation process was tended faster than another day. It caused there was more cellulose contained in it.

Nata de coco has ability to absorb water so that the degradation was being faster. When the water contact in 
the cellulose, there is attacking by microbes which digest the starch (cellulose). The microbes digest this component, leaving behind a porous, sponge-like structure with a high interfacial area, and low structural strength (Kumar Ashwin, et. al, 2011). It changes the properties such plastic shape, tensile strange and plastic color (Roohi, et.al. 2017).

\section{CONCLUSION}

Mechanical properties of biodegradable plastic variations of nata de coco have no significant effect on plastic tensile strength. The highest tensile strength value was $4.3244 \mathrm{Mpa}$ and the highest elongation was $13.9639 \%$ with the highest transmission rate of $14.20 \mathrm{~g} /$ $\mathrm{m}^{2}$ hours. The addition of nata de coco has an effect on the biodegradability test in the soil.

\section{REFERENCES}

Alexia. 2012. Coconut water uses, composition and properties: a review Prades. Fruits. 67 (2): 87-107, doi: 10.1051/fruits/2012002

Apriyani Mery and Endaruji Sedyadi. 2014. Sintesis dan Karakterisasi Plastik Biodegradable dari Pati Onggok Singkong Dan Ekstrak Lidah Buaya (Aloe Vera) dengan Plasticizer Gliserol. J. Sains Dasar 20154 (2) 145 - 152.

Bourtoom, T. 2008. Edible Films Coatings: Characteristics and Propeties. International Food Research Journal. 15 (3)

Gayathry. 2015. Production of Nata de Coco - a Natural Dietary Fibre Product from Mature Coconut Water using Gluconacetobacter xylinum (sju-1). Intl. J. Food. Ferment. Technol. 5(2): 231-235, doi: 10.5958/22779396.2016.00006.4.

Indriyati, L., Indrarti., \& Rahimi, E. 2006. Pengaruh Carboxymethyil Cellulose (CMC) dan Gliserol Terhadap Sifat Mekanik Lapisan Tipis Komposit Bakterial Selulosa. Jurnal Sains Materi Indonesia, 8 (1): 40-44.

Krochta, J., \& E. A. Baldwin, M.-C. (1994). Edible Coatings and films to Improve Food Quality. USA: Technomic Publising Co. Inc.
Kumar Satish and Thakur.2017. Bioplastics - classification, production and their potential food applications. Journal of Hill Agriculture. 8(2): 118-129. doi: 10.5958/22307338.2017.00024.6.

Kumar Ashwin. 2011. Properties of Biodegradable Polymers and Degradation for Sustainable Development. International Journal of Chemical Engineering and Applications. 2 (3).

Kusnandar, F.2010. Kimia Pangan: Komponen Makro. Jakarta: Dyan Rakyat.

Lay and Huey. 1997. Properties of Microstructures of Zain Sheets Flastiazed with Palmitic Acid and Stearic Acid. J. Chereal Chemistry. 74 (1): 83-90.

Mostafa. 2018. Production of biodegradable plastic from agricultural wastes. Arabian Journal of Chemistry. 11, 546553.

Roohi. 2017. Microbial Enzymatic Degradation of Biodegradable Plastics. Current Pharmaceutical Biotechnology. 18 (5), doi: $10.2174 / 1389201018666170523165742$.

Sari, E. 2007. Studi Biodegradasi Poli Hidroksi Butirat pada Medium Cair dan Padat. Tesis. Yogyakarta: Program Pasca Sarjana, Universitas Gadjah Mada.

Sedyadi, E., Aini, S. K., Anggraini, D., Ekawati, D. P. 2016. Starch-Glycerol Based Edible Film and Effect of Rosella (Hibiscus Sabdariffa Linn) Extract and Surimi Dumbo Catfish (Clarias gariepinus) Addition on Its Mechanical Properties. Biology, Medicine, \& Natural Product Chemistry. 5(2): 33-40

Sinaga, L. L., S. Melisa S. R., \& Sinaga, M. S. (2013). Karakteristik Edible Film dari Ekstrak Kedelai dengan Penambahan Tepung Tapioka dengan Gliserol sebagai Bahan Pengemas Makanan. J. Teknik Kimia USU. 2 (4): 12-16.

Sukara Endang and Meliawati Ruth. 2014. Potential Values of BacteriaL Cellulose for industrial applications. Jurnal Selulosa. 4 (1): 7 - 16

Vu Ngo Dinh, et.al. 2017. Lignin and Cellulose Extraction from Vietnam's Rice Straw Using Ultrasound-Assisted Alkaline Treatment Method. International Journal of Polymer Science, doi: $10.1155 / 2017 / 1063695$.

Wirawan, S., Prasetya, A., \& Ernie. (2012). Pengaruh Plasticizer pada Karakteristik Edible Film dari Pektin. Journal Reaktor. 14: 61-67. 